解説

\title{
粉末治金法を利用したポーラス金属の製造プロセスおよび気孔構造制御
}

\author{
小橋 眞* \\ 名古屋大学大学院工学研究科マテリアル理工学専攻, テ 464-8603 名古屋市千種区不老町 1.
}

\section{Processing and Pore Morphology Control of Porous Metals by Powder Processing Route}

\author{
Makoto KOBASHI \\ Dept. Materials Science and Engineering, Graduate School of Engineering, Nagoya University, 1 Furo-cho, Chikusa-ku, Nagoya 464-8603, Japan.
}

Received November 1, 2016; Revised December 18, 2016; Accepted December 19, 2016

\begin{abstract}
Porous metals exhibit various unique physical and mechanical properties, such as low bulk density and high strain energy absorbing capability. The optimum shape of the pores (cell morphology and topology) depends on the required properties. In this paper, two processing methods (precursor method and reactive precursor method) and some attempts to control the cell structure are discussed. Porous aluminum alloys are fabricated by the precursor method. In this method, powder compacted precursor consisting of aluminum and titanium hydride powders are prepared. Upon heating the precursor, titanium hydride decomposes and releases hydrogen gas at around the melting point of aluminum. Then the hydrogen gas produces many pores in aluminum. As for the reactive precursor method, the precursors are made by blending at least two kinds of reactive elemental powders (e.g. aluminum and titanium powders). Closed, flat-disc, open, bimodal-sized and high-porosity open pores are currently achieved by the reactive precursor method.
\end{abstract}

\section{KEY WORDS}

porous metal, metallic foam, combustion reaction, heat of reaction, light material

\section{1 緒 言}

ポーラス材料は, 内部に多量の気孔を含有し, 低比重, 高比剛性（曲げ, ねじり), 衝撃吸収能, 制振性, 流体透過 性（連通気孔の場合）等の緻密材では得ることができないユ ニークな性質を示す.これまで, ウレタンフォームのように ポーラス構造を利用した有機系素材は, 広く利用されている が，2000 年ごろを境にして，ポーラス金属に関する研究報 告が急速に増加した．ポーラス金属の魅力は，単に「気孔が 存在するから軽量である」という単純なものではなく, 気孔 の形により性能が大きく変化し, 多様な機能を素材に付与す ることができる点にある. Table 1 に様々な気孔構造とその 構造により発現する機能とアプリケーションを示す ${ }^{1)}$. 例え ば, 等方性の独立気孔は, かさ密度が 1.0 以下で水に浮くよ うな軽量部材となり, 同時に, 高い衝撃エネルギー吸収能を 示す ${ }^{2}$. Fig. 1 に典型的なポーラス金属の圧縮応力ーひずみ 曲線を示す。ポーラス金属に圧縮荷重を負荷すると, 固体部

* Corresponding author, E-mail: kobashi@numse.nagoya-u.ac.jp
（セル壁部）の曲げ・座屈により全体の変形が進む. そのた め, 一定の圧縮応力でひずみが増大する変形領域を持つ.こ の時の一定の圧縮応力をプラトー応力 $\left(\sigma_{p l}\right)$ と呼び, この変 形領域をプラトー領域と呼ぶ。プラトー応力は, ポーラス金 属の圧縮強度を表す指標として使われ，JIS ${ }^{3,4}$ ， $\mathrm{DIN}^{5)}$ および ISO 規格 ${ }^{(0)}$ では，20～30\% あるいは20４0\%のひずみ範囲の 圧縮応力の平均值として規定されている．プラトー領域を持 つというユニークな圧縮変形挙動により，ポーラス金属は， 高いエネルギー吸収能を示す。次に，気孔が一方向に伸長 し，その配向が揃っているとロータス（れんこん）型と呼ば れる．特に部材全体を直管状の気孔が貫通する時，流体透過 性を示すようになり，熱交換器などへの利用が可能になる. 反対に気孔がへん平で，その配向が揃い層状になっていると 熱伝導率が異方性を示し, 気孔のへん平な面に垂直な方向へ の熱伝導率が低く，断熱効果を示す。さらに，スポンジ構造 の連通気孔型ポーラス金属は，異材と組み合わせて利用する ことが容易であり，電池の電極などに利用されている，ポー ラス金属の表面積は気孔サイズに反比例するので，気孔サイ 
Table 1 Various pore morphology of porous metals and their unique functions.

Category
Closed cell (Equi-axed) Lotus cell (uni-directional)

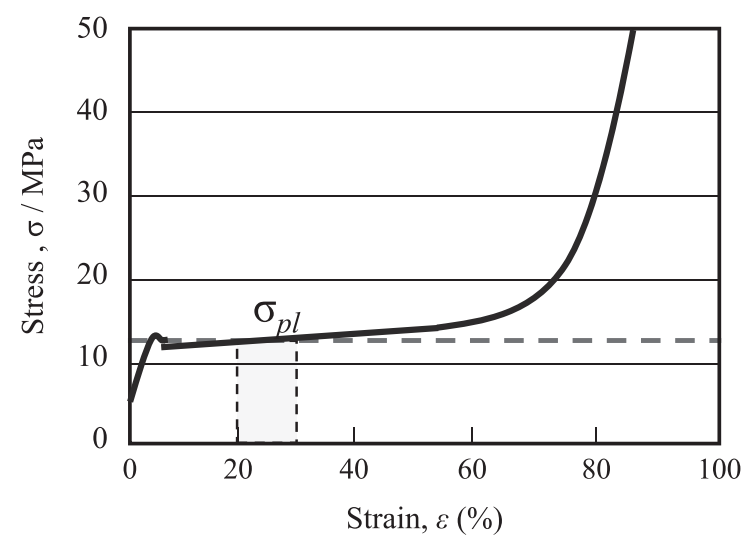

Fig. 1 Typical stress-strain curve for porous metals.

ズをミリスケール $\left(10^{-3} \mathrm{~m}\right)$ からナノスケール $\left(10^{-9} \mathrm{~m}\right)$ に 微細化させれば，ポーラス材料としての表面積は $10^{6}$ 倍に拡 大する.このため, ナノスケール孔を持つポーラス金属は, 触媒やスーパーキャパシ夕電極として優れた性能を示す》。

著者は, アルミニウム粉末と発泡助戍粉末からポーラスア ルミニウムを作製するプロセス（プリカーサ法），および， 元素粉末間の化学反応とその反応熱を利用・制御したポーラ 又金属の気孔構造制御（反応プリカーサ法）に取り組んでい る. 後者である元素粉末間の発熱反応を利用するプロセス は，燃焼合成反応として古くから知られているが，この方法 は生成物に空隙が多く残存し，バルク体を作製する上では課 題となっていた. 著者らは, 空隙の生成を積極的に利用して, その量と形状を制御することに取り組み，ポーラス金属の製 造プロセスとしての可能性を検討している，そこで，本稿で は，プリカーサ法，および，反応プリカーサ法によるポーラ ス金属の製造プロセスについて解説する.

\section{2 プリカーサ法によるポーラスアルミニウムの製造}

本章では，ポーラスアルミニウムの作製方法としてアルミ ニウム粉末を原料とするプリカーサ法について解説する。プ リカーサ法では，Fig. 2 に示すように，まず金属粉末と発泡 助郕粉末を混合し，熱間圧粉，または，押出しなどの加工に

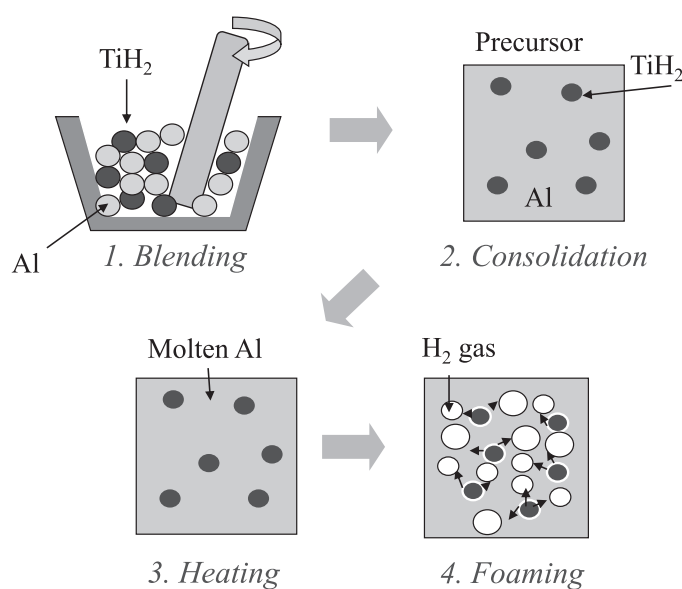

Fig. 2 Schematic illustration of precursor process for porous aluminum.

よりプリカーサと呼ばれる緻密な粉末成型体を作製する. ポーラスアルミニウムを作製する場合には，発泡助戍として 水素化チタン $\left(\mathrm{TiH}_{2}\right)$ 粉末を利用することが多い. 水素化チ タンは約 $450^{\circ} \mathrm{C}$ から次式に示す分解反応により，水素ガスを 放出することが知られている.

$$
\mathrm{TiH}_{2} \rightarrow \mathrm{Ti}+\mathrm{H}_{2} \uparrow
$$

プリカーサの加熱をアルミニウムあるいはアルミニウム合金 の融点付近まで続けると, $\mathrm{TiH}_{2}$ から解離した水素が気泡とな り, 高い気孔率（最大 $90 \mathrm{vol} \%$ 程度）を持つポーラスアルミ ニウムが製造できる。この方法では，試料外表面には，スキ ン層という気泡を含まない緻密な金属層が形成される。一例 として, Al-7Si 粉末 $(<300 \mu \mathrm{m})$ に $\mathrm{TiH}_{2}$ 粉末 $(<45 \mu \mathrm{m})$ を 1.0 mass\% 添加して混合した後に, 熱間圧粉（773 K, $160 \mathrm{MPa})$ により作製したプリカーサの発泡挙動を示す．Fig. 3 は，プ リカーサを $883 \mathrm{~K}$ で加熱し，一定時間保持した後に，冷却し た試料の断面を示す，加熱保持により，気孔が形成し，比較 的長時間 $(240 \sim 600 \mathrm{~s}$ の間), 気孔が安定して保持されるこ とを示している. 次に，Fig.4にプリカーサを中空型の内部 に設置して, 加熱・発泡した後の状態を示す．複数のプリ カーサを一つの鋼製型の内部に設置して加熱しても, 最終的 

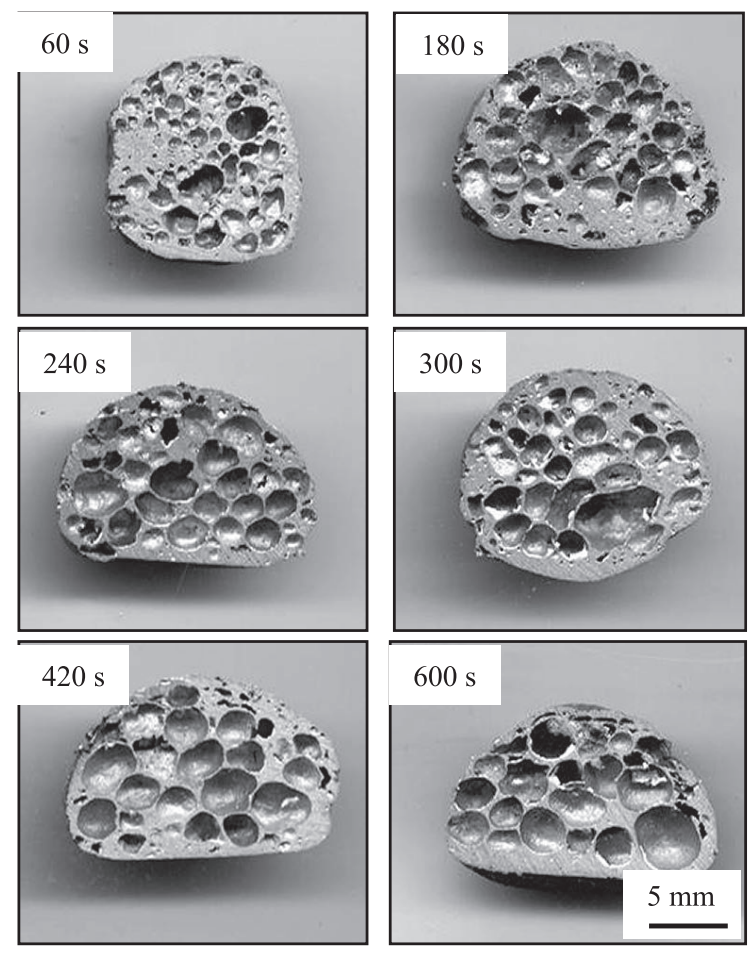

Fig. 3 Cross-section of foamed precursors heated for $60 \sim 600 \mathrm{~s}$ at $883 \mathrm{~K}$.
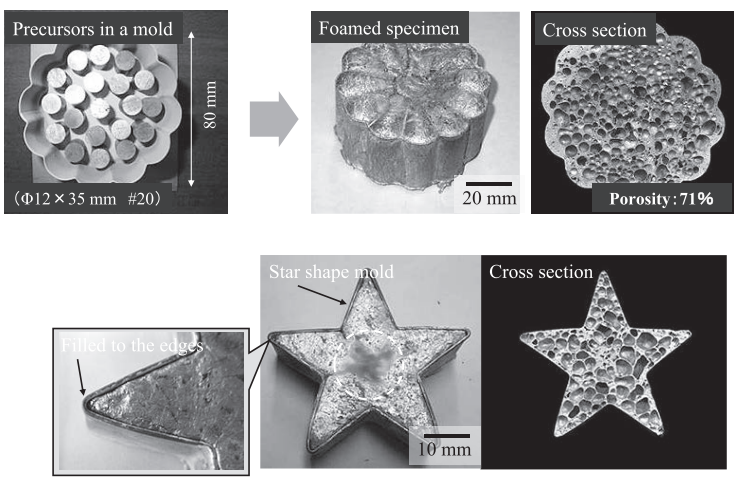

Fig. 4 Porous aluminum foamed in molds.

には全てのプリカーサが一体化し，発泡前のプリカーサの形 状に全く依存しない気孔分布を持つポーラスアルミニウムが 製造できる。また，星形金型の中央にプリカーサを設置し (Fig. 4下段 点線部分)，加熱した場合には，プリカーサは膨 張し, 星形金型の先端部まで, ポーラスアルミニウムが充填 する.このように任意の形状の金型内でプリカーサを発泡さ せることにより，ポーラス構造部材をネットシェイプで製造 することができる.

\section{3 反応プリカーサ法}

\section{1 反応プリカーサ法の概要}

著者らは, 元素粉末間の化学反応とその反応熱を利用・制 御したポーラス金属の合成プロセスおよび気孔構造制御（メ ブ構造制御）に取り組んでいる-16. このプロセスは，燃焼 合成反応 ${ }^{17,18)}$ として古くから知られており, 簡便に高融点化 合物を合成することができる長所を持つ，ただし，燃焼合成
は，生成物に空隙が多く残存し，緻密なバルク体を作製する 上では課題であった。ここでは，空隙の生成を積極的に利用 (促進) して, その量と形状を制御することに取り組み, ポー ラス金属の製造プロセスとしての可能性を検討した結果を示す.

化学反応を利用するプロセスは，Fig. 5 に示すように 2 種 類以上の異なる元素粉末（例えば $\mathrm{Al}$ と $\mathrm{Ti}$ ) を混合し, 圧粉 成形したものをプリカーサとして用いる。プリカーサを加 熱することにより燃焼合成反応を誘起し，化合物（例えば $\left.\mathrm{Al}_{3} \mathrm{Ti}\right)$ を合成する。この時, 反応熱により生成物の温度が上 昇するが，反応熱による試料の最高温度（Peak temperature） が生成物の融点を超えると，もともとプリカーサの中に存在 する雲囲気ガスが生成物中に閉じ込められ独立気孔が生成す る. 詳細は後述するが, 反応時に原料粉末からガス成分（表 面吸着および内部固溶ガス成分）が放出されると気孔率の高 いポーラス構造が得られる. 反対に, 最高温度が生成物の融 点以下であれば，原料粉末間の生成物が固相状態で成長し， 反応が完了した後には, 生成物が連結した構造の連通気孔 (オープンセル) 型ポーラス構造が形成される。このように 気孔形態は, 反応熱量, 試料の最高温度, 反応時に生成する 液相量により大きく変化する。，そこで，次節以降は，発熱助 片や吸熱助剂を添加して反応熱量を制御し，気孔形態を独立 気孔型または連通気孔型に制御した取り組みを紹介する。

3.2 発熱助剂添加による独立気孔の形成プロセス

本節では，Al-Ti 間反応を利用した独立気孔の形成例につ いて紹介する．Fig. 6 に反応プリカーサ法によるAl-Ti 系ポー ラス材料作製の模式図を示す，Al-Ti系試料では，以下に示 す反応を利用する。

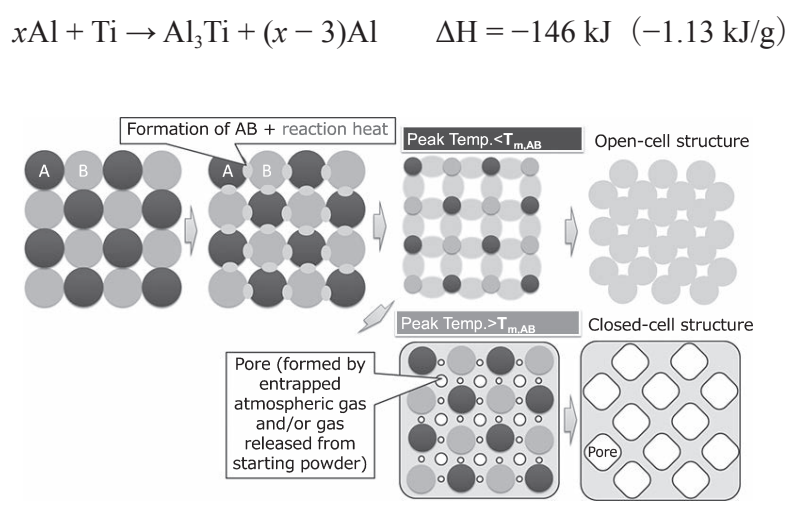

Fig. 5 Schematic illustration of reactive precursor method for synthesizing open-cell and closed cell structures.

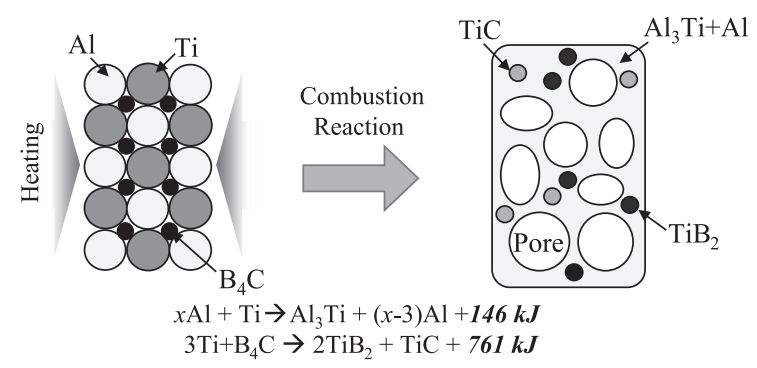

Fig. 6 Schematic illustration of reactive precursor method for porous A1Ti alloys. 


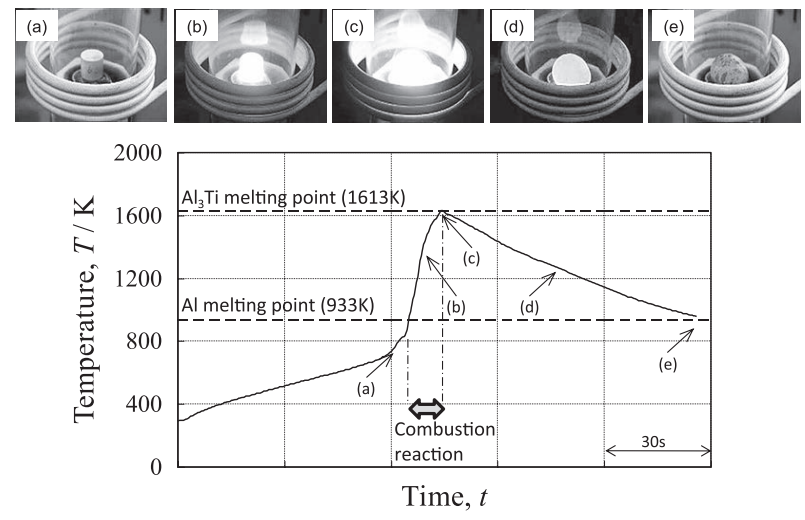

Fig. 7 Combustion behavior and temperature profile during Al-Ti reaction with exothermic agent. Sequential photos (a) (e) represent points indicated by arrows in time-temperature chart.

$x$ は原料粉末混合体における $\mathrm{Al} / \mathrm{Ti}$ モル混合比である.上式 のように, $\mathrm{x} \geqq 3$ の時, $\mathrm{Al}_{3} \mathrm{Ti}$ が反応熱を伴い生成する。また, 反応熱量の制御のために, 次式に示す $\mathrm{B}_{4} \mathrm{C}$ とチタンを発熱助 剤として添加する。

$$
3 \mathrm{Ti}+\mathrm{B}_{4} \mathrm{C} \rightarrow \mathrm{TiC}+2 \mathrm{TiB}_{2} \quad \Delta \mathrm{H}=-761 \mathrm{~kJ}(-3.82 \mathrm{~kJ} / \mathrm{g})
$$

発熱助剂粉末は, $\mathrm{Al}_{3} \mathrm{Ti} / \mathrm{Al}$ 母相中に $\mathrm{TiB}_{2}, \mathrm{TiC}$ 粒子生成量が 5〜 $15 \mathrm{vol} \%$ となるように秤量して添加した。 発熱助剂粉末 の添加により, 燃焼合成反応時の試料の最高温度が上昇し, 燃焼合成による発泡を促進する。この効果に加えて，反応時 に生成する $\mathrm{TiB}_{2}, \mathrm{TiC}$ 粒子が溶融状態の試料中に分散して液 相の見掛けの粘性が向上し気孔が安定する効果もある.

Fig. 7 に Al/Ti モル比 4, 発熱助剤添加量 $10 \mathrm{vol} \%$ の試料に ついて Al-Ti 系ポーラス材料の燃焼合成の様子と温度履歴を 示す。なお，使用した原料粉末の粒径は $\mathrm{Al}$ 粉末， $\mathrm{Ti}$ 粉末と もに $45 \mu \mathrm{m}$ 以下で, プリカーサは圧力 $165 \mathrm{MPa}$ で成形した. また，加熱雾囲気は $\mathrm{Ar}$ 雾囲気とした。温度履歴から $\mathrm{Al}$ の 融点付近で温度が急激に上昇し, $\mathrm{Al}_{3} \mathrm{Ti}$ の融点付近で温度の ピークを迎えていることが分かる，燃焼合成反応中の試料 は，自己発熱で赤熱し，膨張して外形状が球形になる。その 後は, 外形状に大きな変化は見られない. $\mathrm{A} 1$ と $\mathrm{Ti}$ の燃焼合 成反応は $\mathrm{Al}$ の融点付近 $\left(\right.$ 約 $\left.660^{\circ} \mathrm{C}\right)$ で開始することが知ら れており ${ }^{19,20)}$, Fig. 7 の温度履歴はこれらの報告とよく一致す る. また, 最高温度が $\mathrm{Al}_{3} \mathrm{Ti}$ の融点に達していることから, 反応熱によって気孔の生成, 成長に必要不可欠な液相が生じ ていると判断される．燃焼合成反応時の気孔の形成過程を観 察するために，燃焼合成反応中の試料をX 線で透過した結 果を Fig. 8 に示す。燃焼合成反応の開始とともに, 微細な気 孔が形成し，反応開始から約 $400 \mathrm{~ms}$ でほぼ，プリカーサの 膨張は停止し, 試料内部で気孔の合体成長が生じることがわ かっている ${ }^{21)}$.

原料粉末の固化成形体（プリカーサ）を加熱して $\mathrm{Al}$ と $\mathrm{Ti}$ の発熱反応を誘起すると, Fig. 9 に示すように粉末表面に吸 着した水素や，粉末中に固溶した水素がガス化し，気孔を 生成することがわかっている。同様の気孔生成メカニズム

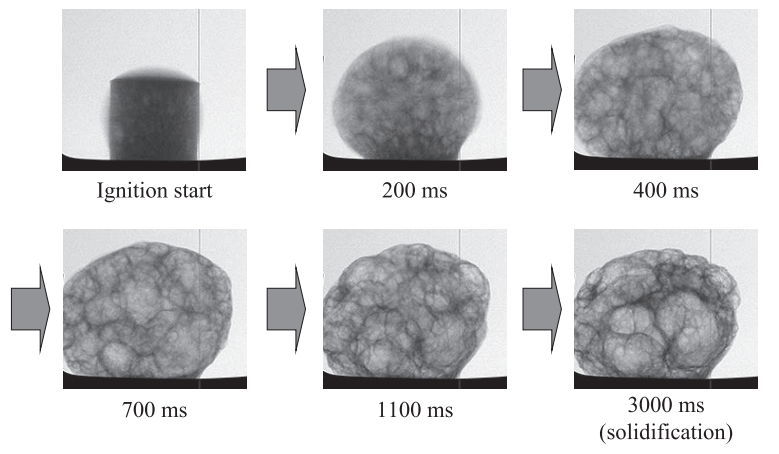

Fig. 8 X-ray transparent images of foaming behavior for Al-Ti precursor with exothermic agent.

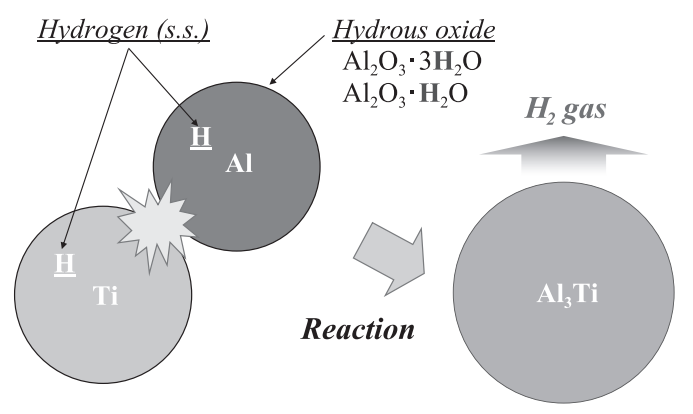

Fig. 9 Schematic illustration of gas-generation mechanism.

Table 2 Composition of $\mathrm{C}, \mathrm{O}$ and $\mathrm{H}$ in $\mathrm{Ni}$,Al,Ti powder.

\begin{tabular}{lccl}
\hline & $\mathrm{C}$ & $\mathrm{O}$ & \multicolumn{1}{c}{$\mathrm{H}$} \\
\hline Ni powder & 0.060 & 0.13 & 0.0055 \\
Al powder & 0.003 & 0.26 & 0.00078 \\
Ti powder & 0.006 & 0.33 & 0.0066 \\
\hline
\end{tabular}

Unit: $\operatorname{mass} \%$

Table 3 Gas composition in the pores.

\begin{tabular}{lccccc}
\hline Gas & $\mathrm{H}_{2}$ & $\mathrm{CH}_{4}$ & $\mathrm{Ar}$ & $\mathrm{N}_{2}, \mathrm{CO}$ & Total \\
\hline mass $\%$ & 68.7 & 19.6 & 8.7 & 3.0 & 100 \\
\hline
\end{tabular}

はYiらによっても報告されている ${ }^{19}$. Al-Ni 間の燃焼合成反 応を利用した発泡プロセスで，原料粉末に含まれている（表 面吸着および内部固溶) 水素, 酸素, 炭素の定量分析と気孔 内のガス組成を定量分析した結果をそれぞれ Table 2 および Table 3 に示す。気孔内のガス成分の 68 mass\% が $\mathrm{H}_{2}$ であり， 原料粉末表面の結晶水, または, 粉末内部に固溶していた水 素が発泡の重要な因子であると推定される。

Fig. 10 に $\mathrm{Al} / \mathrm{Ti}$ モル比 $=3 \sim 10$, 発熱助剤添加量 0 ～ $15 \mathrm{vol} \%$ のプリカーサを用いて作製した $\mathrm{Al} / \mathrm{Al}_{3} \mathrm{Ti}$ 複合ポーラス材料の 断面写真を示す。発熱助剂を添加しない場合は, $\mathrm{Al} / \mathrm{Ti}$ モル 比が 5 の試料が最も高い気孔率 $(63 \%)$ を示した。 $\mathrm{Al} / \mathrm{Ti}$ モ ル比が 10 の試料では, 気孔の生成が少ないが, これは, $\mathrm{Al} /$ $\mathrm{Ti}$ モル比の増加によって十分な発熱が得られず, $\mathrm{H}_{2}$ ガスの 発生が不十分だったためである。一方，発熱助剤を添加する と, $\mathrm{Al} / \mathrm{Ti}$ モル比 $=3 \sim 10$ の全ての組成で気孔率が上昇した. 


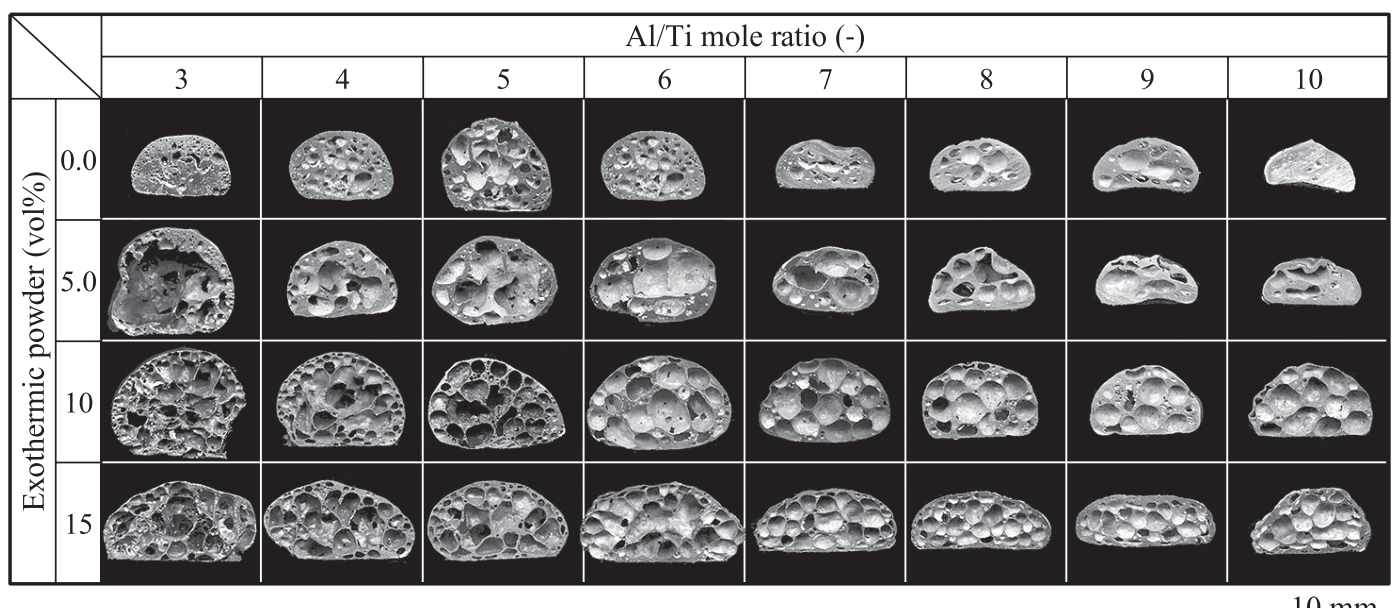

$10 \mathrm{~mm}$

Fig. 10 Cross sections of $\mathrm{Al} / \mathrm{Al}_{3} \mathrm{Ti}$ porous composites synthesized from precursors of various $\mathrm{Al} / \mathrm{Ti}$ mole ratios and exothermic powder additions. (Al/Ti mole ratio: $3 \sim 10$, exothermic powder addition: $0 \sim 15 \mathrm{vol} \%$ ).

添加量 $10,15 \mathrm{vol} \%$ では $\mathrm{Al} / \mathrm{Ti}$ モル比 $=10$ でも $60 \%$ 以上の気 孔率を示し, 全体に $80 \%$ 近くの高い気孔率が得られた。こ のように, 広い $\mathrm{Al} / \mathrm{Ti}$ 組成で発熱助剂が気孔率向上に有効で あることが明らかである。

\section{4 連通気孔型ポーラス材料の合成}

ここでは燃焼合成の原料として $\mathrm{Ti}$ 及び $\mathrm{B}_{4} \mathrm{C}$ 粉末を用いて, 次式に示す反応により, $\mathrm{TiB}_{2}, \mathrm{TiC} / \mathrm{Ti}$ 複合材料を合成し, 気 孔形態を制御する方法について述べる.

$$
x \mathrm{Ti}+\mathrm{B}_{4} \mathrm{C} \rightarrow 2 \mathrm{TiB}_{2}+\mathrm{TiC}+(x-3) \mathrm{Ti}
$$

$x(>3)$ は Ti と $\mathrm{B}_{4} \mathrm{C}$ のモル混合比で, この Ti が母相となり, そ の中に $\mathrm{TiB}_{2}, \mathrm{TiC}$ 粒子が分散する微視組織を呈する。ここで は，連通気孔を形成する目的で，燃焼合成による温度上昇を 制御する材料として, 反応には関与せず反応熱を吸収する物 質を吸熱助剂として用い，吸熱助剤が気孔形態に及ぼす影響 について述べる。まず，原料粉末（Ti: $\left.<45 \mu \mathrm{m}, \mathrm{B}_{4} \mathrm{C}:<45 \mu \mathrm{m}\right)$ をモ儿混合比が $\mathrm{Ti} / \mathrm{B}_{4} \mathrm{C}=3 \sim 10$ となるように秤量した後, 吸 熱助剂粉末として $\mathrm{TiB}_{2}$ 粒子 $(63 \mu \mathrm{m})$ または $\mathrm{SiC}$ 粒子 $(<15 \mu \mathrm{m}$, $<40 \mu \mathrm{m},<150 \mu \mathrm{m})$ を試料全体の 0 ～ $15 \mathrm{vol} \%$ となるように添 加した後に，乳鉢を用いて十分に混合した．この混合粉末約 $5 \mathrm{~g}$ を直径 $15 \mathrm{~mm}$ の円柱状に圧粉成形した。 压粉体を高周波 誘導炉内に設置し，アルゴン䨌囲気下で加熱して燃焼合成反 応を誘起した。

Fig. 11 に Ti $/ \mathrm{B}_{4} \mathrm{C}$ モル混合比 3 , 吸熱助剂非添加の粉末組成 で作製した試料の燃焼合成反応後の断面写真を示す． $\mathrm{Ti} / \mathrm{B}_{4} \mathrm{C}$ モル混合比が 3 の時は，七ル壁部分は高融点であるセラミッ クス $\left(\mathrm{TiB}_{2}, \mathrm{TiC}\right)$ のみであるものの, 反応熱量も高く, 試料 の中央部分では, 数 $\mathrm{mm}$ を超えるような粗大な空隙が生成し た。これは, 反応過程で生成した融液が凝集したことによ る. そこで, 吸熱助剤として $\mathrm{TiB}_{2}$ 粒子を添加した試料の断 面写真を Fig. 12, 13 に, 燃焼合成反応時の試料の温度変化 を Fig. 14 に示す．吸熱助戍として $\mathrm{TiB}_{2}$ を添加することによ り, 燃焼合成反応時の温度上昇が抑制され, 気孔形態も微細
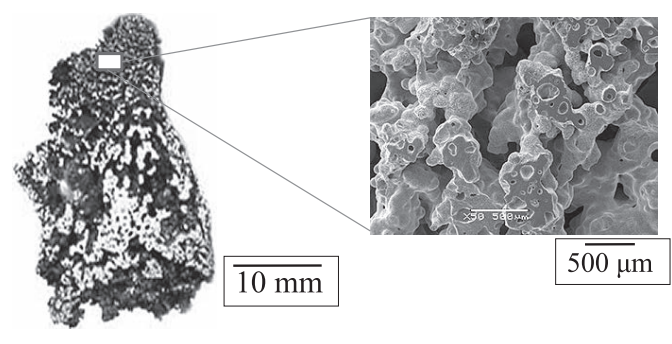

Fig. 11 Cross section of porous $\mathrm{TiB}_{2}, \mathrm{TiC}$ composite without endothermic agent.

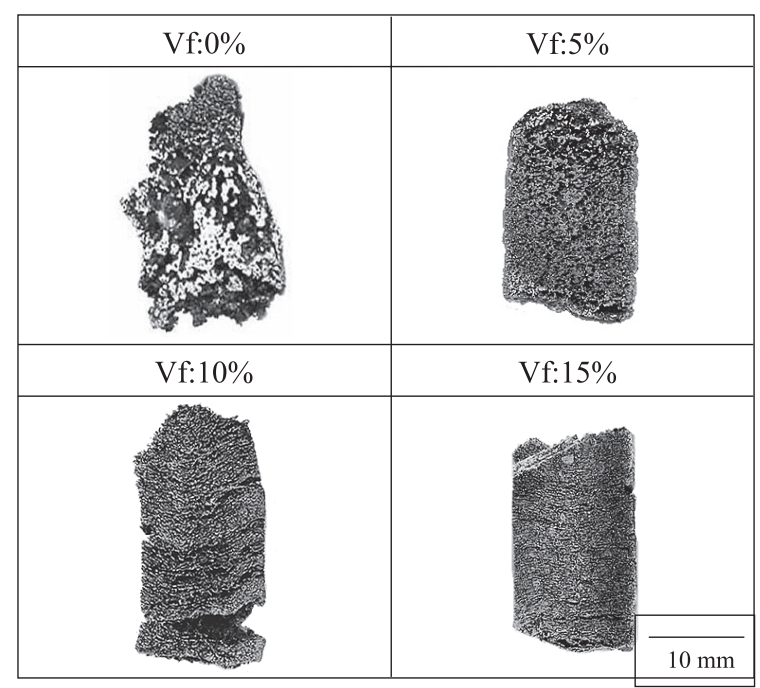

Fig. 12 Cross sections of porous $\mathrm{TiB}_{2} / \mathrm{TiC}$ composites with endothermic agent additions of $0 \sim 15 \mathrm{vol} \%$.

な連通気孔に変化することが理解できる，また，吸熱助剂と して粒子サイズの異なる $\mathrm{SiC}$ を用いた例を Fig. 15 に示す. 吸熱助剂の粒径を微細化することにより, 燃焼合成後の試料 の気孔サイズも微細化する。

Fig. 16 に Ti/ $\mathrm{B}_{4} \mathrm{C}$ モル混合比を 3 10, 吸熱助剂 $\left(\mathrm{TiB}_{2}\right)$ 添 加量を $0 \sim 15 \mathrm{vol} \%$ で変化させた試料の気孔形態を示す. 発 熱助剂の例と同様に, この場合も広い $\mathrm{Ti} / \mathrm{B}_{4} \mathrm{C}$ モル混合比で, 

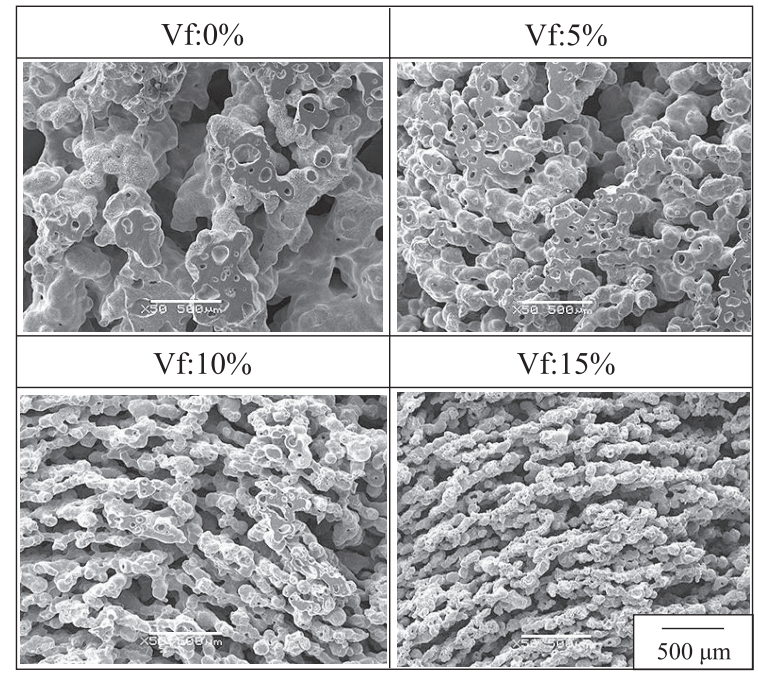

Fig. 13 Pore structures of porous $\mathrm{TiB}_{2} / \mathrm{TiC}$ composites with endothermic agent additions of $0 \sim 15 \mathrm{vol} \%$.

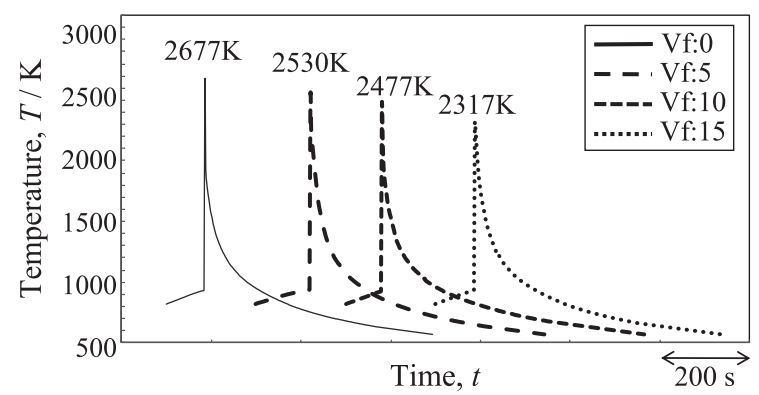

Fig. 14 Temperature change of specimens with endothermic agent powder addition (Vf: 0-15\%).
吸熱助剤を添加することにより，微細な連通気孔が形成する ことが明らかである。

\section{5 反応法により合成できる様々な気孔形態}

Fig. 17 に反応プリカーサ法により製造したポーラス金属 の様々な気孔形態を示す，前章までに示したように独立型や 連通型の気孔だけでなく，様々な気孔形態を得ることができ る.プリカーサの一端部のみを加熱して，燃焼合成反応を自 己伝播させる自己伝播モードにより，扁平気孔を形成するこ ともできる。 また，スペーサー粒子（燃焼合成後に除去可能

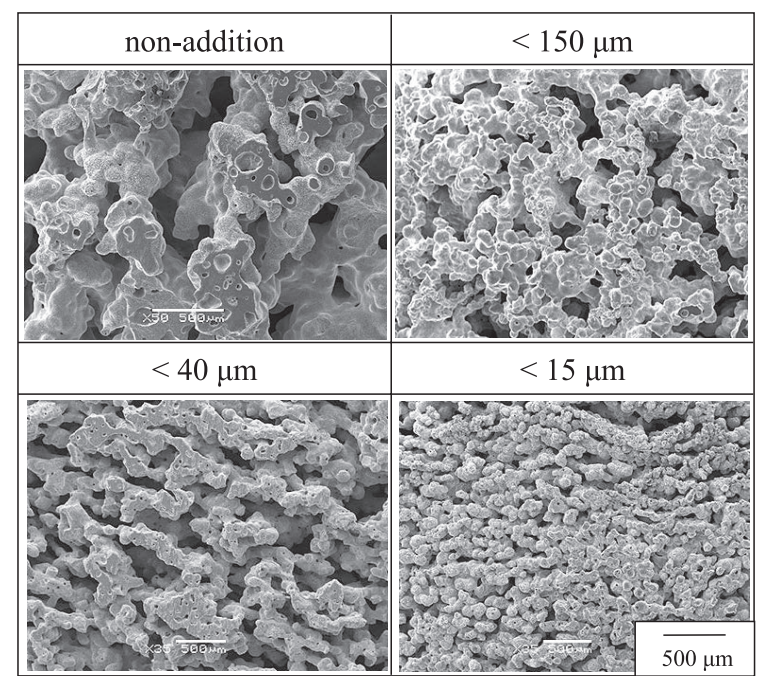

Fig. 15 Pore structures of porous $\mathrm{TiB}_{2} / \mathrm{TiC}$ composites with endothermic agent additions of various sizes.

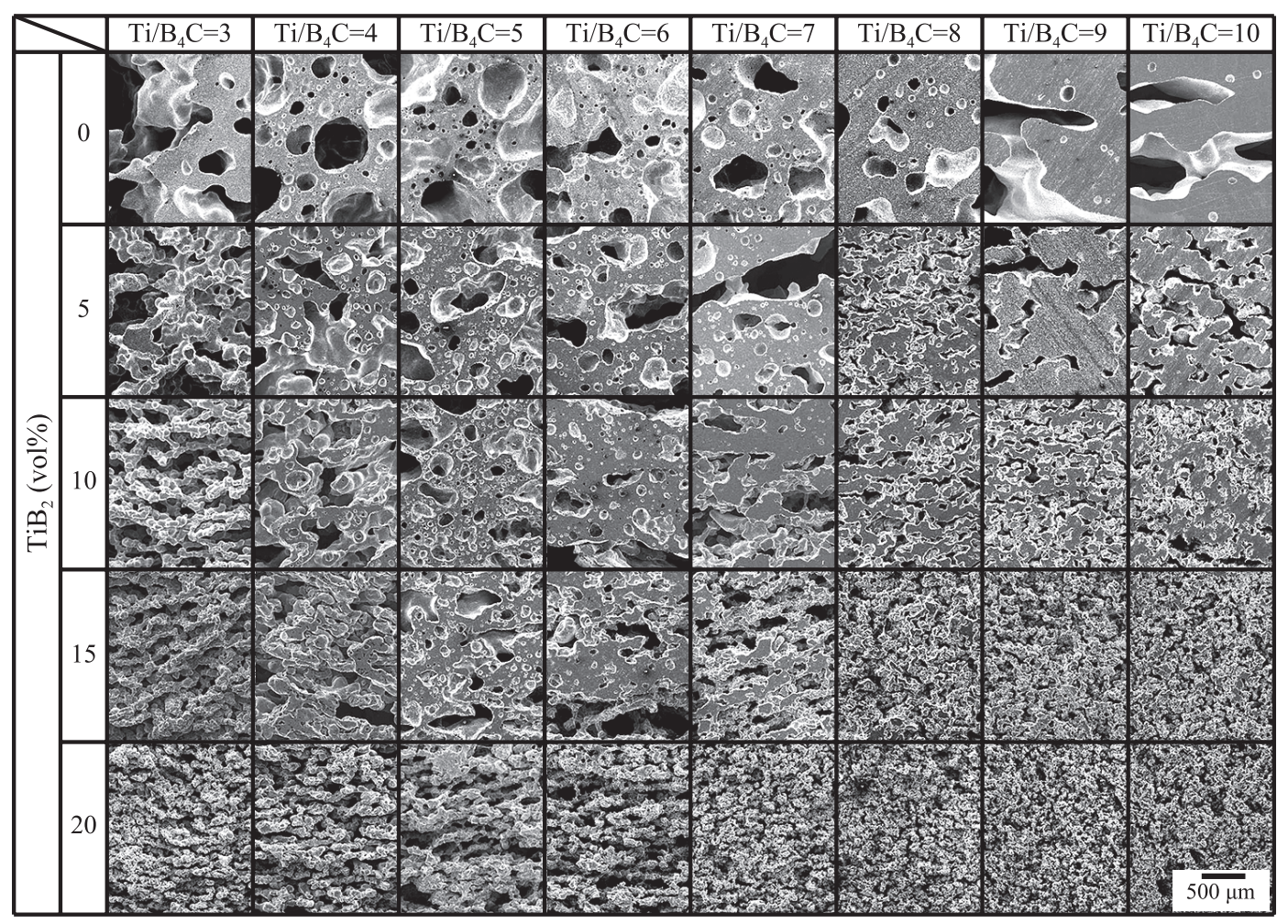

Fig. 16 Pore structures of porous $\mathrm{TiB}, \mathrm{TiC} / \mathrm{Ti}$ composites with various $\mathrm{Ti} / \mathrm{B}_{4} \mathrm{C}$ blending ratios and volume fractions of endothermic agent $\left(\mathrm{TiB}_{2}\right)$. 


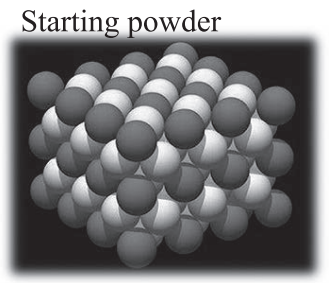

Hierarchical cell

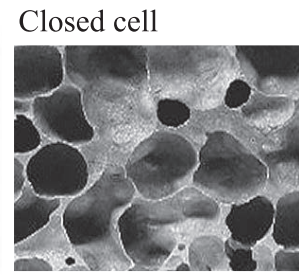

Porous surface

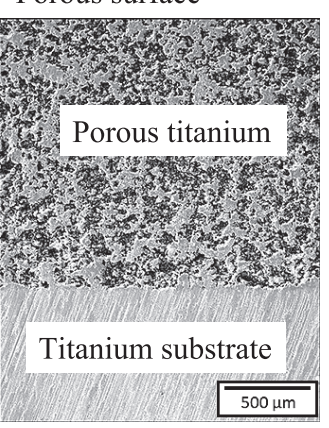

Open cell

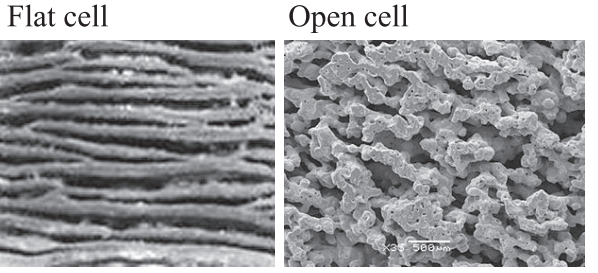

Hybrid with hollow tube
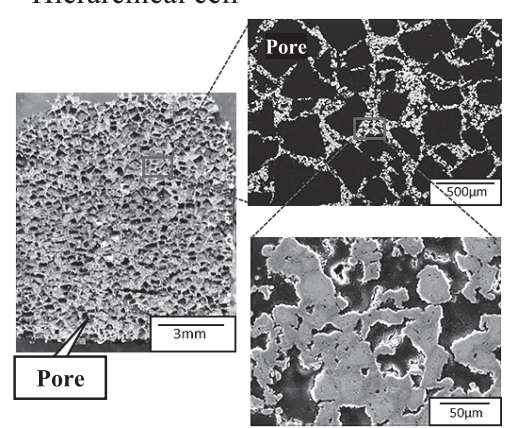

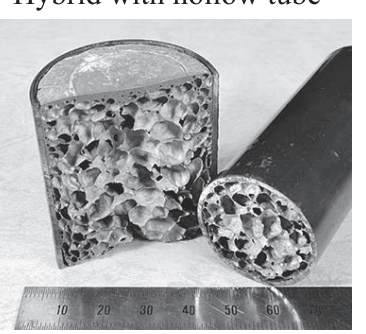

Fig. 17 Varieties of pore structures achieved by reactive precursor method.

な粒子）を用いると，燃焼反応により形成する連通孔に加え て，スペーサー除去により気孔が形成されるので，大小 $2 つ$ の気孔径を持つ階層構造ポーラス金属を得ることができる ${ }^{22)}$. 中空部材内部で反応を誘起すれば，中空部材内部にポーラス 金属が充填する部材を得ることも可能である.

\section{6 ま め}

粉末治金プロセスによるポーラス金属の製造方法，およ び，気孔構造の制御について述べた。プリカーサ法は，既に 多くの研究実績があり，信頼性の高いポーラス金属の製造方 法であるが，その適用範囲がアルミニウム合金にかぎられて いて, 高融点化合物のような物質への適用ができない. また, 気孔構造も独立気孔に限定される。著者らが開発した反応プ リカーサ法は，金属間化合物やセラミックなど，高融点化合 物への適用が可能であり, また多様な気孔構造が得られる. 今後は, 個々のアプリケーションに特化した気孔構造の最適 化に関するプロセス開発を行っていく予定である.

\section{文献}

1) M. F. Ashby, A. G. Evans, N. A. Fleck, L. J. Gibson, J. W. Hutchinson, H. N. G. Wadley: Metal Foams: A Design Guide, Butterworth-Heinemann, (2000) 3-5.

2) N. Kanetake: Sosei to kakou, 586 (2009) 1004-1008.

3) Japanese Standard Association: Compression test for porous metals and cellular metals, JIS H7902, (2008).

4) Japanese Standard Association: High speed compression test for porous metals and cellular metals, JIS H7904, (2012).

5) Deutsches Institut für Normung: Compression test of metallic cellular materials DIN 50134, DIN, (2008).

6) ISO International Standard: Compression test for porous and cellular metals ISO 13314, (2011).

7) X. Y. Lang, A. Hirata, T. Fujita, M. W. Chen: Nature Nanotechnology,
(2011) http://dx.doi.org/10.1038/NNANO.2011.13.

8) M. Kobashi, S. Miyake, N. Kanetake: Intermetallics, 42 (2013) 32-34.

9) Y. Arakawa, M. Kobashi, N. Kanetake: Intermetallics, 41 (2013) 22-27.

10) M. Kobashi, S. Murata, N. Kanetake: J. Materials Science Research, 1 (2012) 1-10.

11) Y. Arakawa, M. Kobashi, N. Kanetake: Materials, 5 (2012), 1267-1274.

12) M. Kobashi, Y. Kamiya, N. Kanetake: Materials Science \& Engineering A, 556 (2012) 388-394.

13) Y. Arakawa, M. Kobashi, N. Kanetake: J. Japan Inst. Met. Mater., 75 (2011) 379-385.

14) M. Kobashi, N. Kanetake: Materials, 3 (2010) 3939-3947.

15) M. Kobashi, N. Inoguchi, N. Kanetake: Intermetallics, 18 (2010) 1102-1105.

16) M. Kobashi, N. Inoguchi, N. Kanetake: Intermetallics, 18 (2010) 1039-1045.

17) A. G. Merzhanov, I. P. Borovinskaya: Self-Propagating HighTemperature Synthesis of Inorganic Compounds, Doklady Akademii Nauk SSSR, 204 (1972) 366-369.

18) A. G. Merzhanov: International Chemical Engineering, 20 (1980) 150-171.

19) H. C. Yi, A. Petric, J. J. Moore: J. of Materials Science, 27 (1992) 6797-6806.

20) P. Shen, B. Zou, S. Jin, Q. Jiang: Materials Science and Engineering A, 454-455 (2007) 300-309.

21) Y. Arakawa, C. Jiménez, F. García-Moreno, J. Banhart, A. Racke, M. Kobashi, N. Kanetake: Procedia Materials Science, 4 (2014) 268-272.

22) M. Kobashi, S. Miyake, N. Kanetake: Intermetallics, 42 (2013) 32-34. 